\title{
Rizobacteria Isolated in the Amazon and Its Influence on the Growth of Guarana Seedlings
}

\author{
Lais Alves da Gama ${ }^{1}$, Karla Gabrielle Dutra Pinto ${ }^{1}$, Bruna Nogueira Leite ${ }^{1}$, Gerlandio Suassuna Gonçalves ${ }^{1}$, \\ José Odair Pereira $^{1}$, José Ferreira da Silva ${ }^{1} \&$ Sônia Maria Figueiredo Albertino ${ }^{1}$ \\ ${ }^{1}$ Federal University of Amazonas, Manaus, Amazonas, Brazil \\ Correspondence: Lais Alves da Gama, Federal University of Amazonas, Manaus, Amazonas, Brazil. E-mail: \\ lais_alves_@hotmail.com
}

Received: November 21, 2018

Accepted: January 24, 2019 Online Published: March 15, 2019

doi:10.5539/jas.v11n4p428

URL: https://doi.org/10.5539/jas.v11n4p428

\begin{abstract}
Guarana (Paullinia cupana var. Sorbilis (Mart.) Ducke) is a species native from Amazon which has high caffeine concentration. The interactions between guarana and microorganisms in Amazonian soils need to be investigated, especially in relation to the seedling production process, due to its beneficial relationships such as biosynthesis and the supply of stimulating substances, which may result in shortening of the nursery garden or increased productivity. Thus, this research had the objective of evaluating the potential of growth caused by rhizobacteria (Burkholderia ambifaria and Bacillus sp.) in rooting of guarana seedlings. The root length, volume, dry matter of the aerial part, height, number of leaves, leaf area and dry matter of shoot were evaluated at 180 days after planting emergence. Were also determined the carbohydrate and proline content of the aerial part. The rhizobacteria did not influence the growth of the seedlings, however, the carbohydrate contents were higher when the inoculation of the rhizobacteria was carried out with the Burkholderia ambifaria bacteria in the cultivar BRS-Amazonas, with the best results. The proline levels were higher in the control treatment of the two cultivars.
\end{abstract}

Keywords: microorganisms, auxin, seedling production, carbohydrate, proline

\section{Introduction}

Guarana (Paullinia cupana var. Sorbilis (Mart.) Ducke) is a species native to the Amazon region, known for its energetic and medicinal properties and because it has a higher concentration of caffeine than coffee, mate and cocoa. The production of guarana providing employment and income for producers in the Amazon (Schimpl, Silva, Carvalho Gonçalves, \& Mazzafera, 2013).

Plant growth promoting rhizobacteria (RPCP) are found in free life in the soil and can be associated with some plants, promoting benefits to it. These benefits are related to the biosynthesis and supply of growth-stimulating substances essential in various physiological aspects. Among these growth-promoting substances, auxins stand out as the main and most responsive stimulators (Galdiano, 2009).

There are numerous genera of rhizobacteria, but great emphasis has been given to the genera Bacillus and Burkholderia, known for their benefits as growth promoters. Plant growth promoting rhizobacteria (RPCP) promote plant growth and development through nitrogen fixation, siderophores production and growth regulators, these benefits can increase the biomass of the plant, so that its development entails in the shortening of the nursery time or in the increase of its productivity, depending on the plant species and the bacterial isolate (Grobelak, Napora, \& Kacprzak, 2015).

Environmentally, the use of these micro-organisms may be preferable to the use of fertilizers and pesticides, not only for the least cost and time, but for contributing to a sustainable agricultural system and reducing the problems associated with the use of chemicals (Baldani, 2007; Avis, Gravel, Antoun, \& Tweddell, 2008; Solano, Maicas, \& Mañero, 2008).

The beneficial relationship between plant and microorganisms is an alternative to improve aspects of cultivation, such as seed production, macro and micropropagation, reduction of nursery production costs due to the shorter plant use time and even the increase productivity. 
Although there are many studies emphasizing the beneficial association of RPCPs with several species of plants, as well as the genetic knowledge of these microorganisms, there is no information in the literature about these studies with guarana. Therefore, this research has the objective of evaluating the potential of growth promoting rhizobacteria in the rooting of guarana seedlings.

\section{Method}

\subsection{Plant Materials}

The guarana seeds of BRS-Amazonas and BRS-Maués cultivars were obtained from the Jayoro farm, located in the municipality of Presidente Figueiredo, $120 \mathrm{~km}$ from the city of Manaus, in the State of Amazonas. After collection of the fruits, the aril was removed from the seeds in running water, followed by washing in distilled water and immersion in $10 \%$ sucrose solution for 30 minutes.

\subsection{Bacterial Cultures}

The rhizobacteria used were Burkholderia ambifaria and Bacillus sp., as identified by Batista (2013) and assigned by the Biotechnology Laboratory of the Biological Sciences Institute (UFAM), and they were isolated from the guarana roots of Farm Santa Helena, Maués, Amazonas, Brazil. Bacterial suspensions were prepared from the multiplication of $108 \mathrm{CFU} \mathrm{mL}^{-1}$ strains, transferred to the elenmeyer flask containing $50 \mathrm{~mL}$ of Luria-Bertani liquid medium (LB), under $150 \mathrm{rpm}$ orbital shaking at $28{ }^{\circ} \mathrm{C}$ for 24 hours. After this procedure, $200 \mu \mathrm{L}$ of the solution were removed with the bacterial lines and placed in $0.5 \mathrm{~mL}$ identified microtubes and 200 $\mu \mathrm{L}$ of $15 \%$ glycerol added, which were stored in a freezer at $-80^{\circ} \mathrm{C}$.

\subsection{Place of Study}

The experiment started in February 2014, conducted in a greenhouse and at the Weed Science Laboratory (LCPD) of the Federal University of Amazonas (UFAM), Manaus-AM.

\subsection{Inoculation of Bacterial}

For inoculation, the seeds were sprayed with the bacterial suspension at the concentration of $10^{8} \mathrm{CFU} \mathrm{mL}^{-1}$, placed in plastic bags, shaken for 30 minutes to promote the uniform contact of the seeds with the bacteria, and then were seeded in plastic trays containing the bark of the guarana fruits, previously tanned and sifted, as substrate. The trays containing the seeds were irrigated three times a week in a greenhouse and no nutrient solution was added to them.

Ninety days after sowing, when the seedlings reached the height of about $10 \mathrm{~cm}$ and were a pair of well-defined leaflets, they were removed from the trays and again inoculated with the bacterial isolates by immersing the root system for 30 minutes. After inoculation, the seedlings were transplanted into black polyethylene bags measuring $23 \times 18 \mathrm{~cm}$, containing as substrate, a mixture of soil and sand, in a ratio of 4:1. Treatments without inoculation of microorganisms (control) were only peaked directly into the polyethylene bags. The seedlings remained in greenhouse, receiving three irrigations weekly.

\subsection{Experimental Design}

The experimental design was a completely randomized block design, with four replications, in a $2 \times 2+2$ factorial scheme, where the factors are: two guarana cultivars (BRS-Amazonas and BRS-Maués), two rhizobacteria (Burkholderia ambifaria and Bacillus sp.) and control group one for each cultivar. The experimental unit consisted of ten plants, with four replicates.

\subsection{Measures Assessed}

At 180 days after sowing, the seedlings were removed from the polyethylene bags, root and aerial part of the plant were separated and washed in running water, obtaining the root system intact for annotation of the following characteristics: number of secondary roots, length of root pivoting and root volume. The measurement of the length was with the aid of a ruler and the diameter with a digital caliper. Root volume was measured by the displacement of water caused by the introduction of the roots into a graduated beaker.

The height of the aerial part (APA) was measured using a millimeter ruler and the leaf area of all leaves by means of the "Area Meter" (Liquor Inc., Lincon, Nebrasca, US). The root system and the aerial part of each plant were placed in paper bags for later oven drying with forced ventilation at $70{ }^{\circ} \mathrm{C}$ until constant weight. The weight of the dry matter of the aerial part (PSPA) and the dry matter weight of the root system (PSSR) were determined with the aid of an analytical balance. 
Proline quantification was performed according to Rena and Masciotti (1976). The quantification of the total soluble sugars was by reaction with anthrone, according to methodology recommended by MCcready, Guggolz, Silviera, and Owens (1950).

\subsection{Statistical Analysis}

The data were submitted to analysis of variance and Tukey and Scott Knott tests at 5\% of significance for comparison of means with the aid of statistical software.

\section{Results}

\subsection{Biometry and Proline}

Regardless of the interaction, the rhizobacteria had no beneficial effect on the variables, shoot dry matter, root dry matter, total dry matter, root diameter and leaf area, presenting lower mean values in relation to the control treatment. Among the rhizobacteria, there was no significant difference in relation to the evaluated characteristics (Table 1).

Table 1. Mean of the dry matter of shoot (DMS), root (DMR) and total (DMT), root diameter (RD), proline (PRO) and leaf area (LA) of guarana seedlings from inoculated seeds with Bacillus sp. and Burkholderia ambifaria, independent of the cultivar, Manaus-2015

\begin{tabular}{|c|c|c|c|c|c|c|}
\hline Treatments & DMS & DMR & DMT & $\mathrm{RD}$ & PRO & LA \\
\hline & \multicolumn{3}{|c|}{---------------- g plant ${ }^{-1}$---------------- } & $\mathrm{mm}$ & $\mu \mathrm{mol} \mathrm{g}{ }^{-1}$ & $\mathrm{~cm}^{2}$ \\
\hline Control & $1.85 \mathrm{a}$ & $0.65 \mathrm{a}$ & $2.51 \mathrm{a}$ & $3.92 \mathrm{a}$ & $4.31 \mathrm{a}$ & $14.20 \mathrm{a}$ \\
\hline Bacillus sp. & $1.37 \mathrm{~b}$ & $0.43 \mathrm{~b}$ & $1.95 \mathrm{~b}$ & $3.37 \mathrm{~b}$ & $3.55 \mathrm{~b}$ & $12.84 \mathrm{ab}$ \\
\hline Burkholderia ambifaria & $1.34 \mathrm{~b}$ & $0.42 \mathrm{~b}$ & $1.85 \mathrm{~b}$ & $3.32 \mathrm{~b}$ & $3.52 \mathrm{~b}$ & $12.43 \mathrm{~b}$ \\
\hline C.V. $(\%)$ & 11.41 & 13.43 & 11.33 & 11.42 & 12.20 & 6.74 \\
\hline
\end{tabular}

Note. Means followed by the same letters in the column, do not differ among themselves to $5 \%$ of probability by the test of Tukey.

For the proline variable, the values found in the control treatment were higher than the treatments with the rhizobacteria (Table 1).

There were no interactions between the guarana cultivars and the rhizobacteria with respect to the height, leaf number, root length, leaf area and proline. However, all these characteristics were significant (Table 2).

Table 2. Mean of height (HEI), number of leaves (NL), root length (RL), leaf area (LA) and proline content (PRO) of two guarana cultivars, regardless of inoculation with the bacteria. Manaus-2015

\begin{tabular}{llllll}
\hline Cultivars & HEI & NL & RL & LA & PRO \\
\hline & $\mathrm{cm}$ & - & $\mathrm{cm}$ & $\mathrm{cm}^{2}$ & $\mu \mathrm{mol} \mathrm{g}^{-1}$ \\
BRS Amazonas & $10.52 \mathrm{~b}$ & $2.77 \mathrm{a}$ & $32.93 \mathrm{a}$ & $13.68 \mathrm{a}$ & $3.48 \mathrm{~b}$ \\
BRS Maués & $11.43 \mathrm{a}$ & $2.66 \mathrm{~b}$ & $23.18 \mathrm{~b}$ & $12.64 \mathrm{~b}$ & $4.11 \mathrm{a}$ \\
C.V. $(\%)$ & 6.07 & 3.25 & 15.11 & 6.74 & 12.20 \\
\hline
\end{tabular}

Note. Means followed by the same letters in the column, do not differ among themselves to $5 \%$ of probability by the test of Tukey.The cultivar BRS-Amazonas was superior to BRS-Maués in relation to leaf number, root length and leaf area, however, it presented lower proline content and lower size.

The interaction between rhizobacteria and guarana cultivars showed a significant difference in relation to dry matter, but was not significant in relation to root length (Table 3 ). 
Table 3. Mean of root dry matter (RDM) and root length (RL) of the interaction between the bacteria (Bacillus sp. and Burkholderia ambifaria) and the cultivars (BRS Amazonas and BRS Maués) of guarana, Manaus-2015

\begin{tabular}{|c|c|c|c|}
\hline \multirow{2}{*}{ Cultivars } & \multicolumn{2}{|c|}{ RDM (g plant $\left.{ }^{-1}\right)$} & \multirow{2}{*}{ Control } \\
\hline & Bacillus sp. & Burkholderia ambifaria & \\
\hline BRS-Amazonas & $0.41 \mathrm{aB}$ & $0.52 \mathrm{aAB}$ & $0.63 \mathrm{aA}$ \\
\hline BRS-Maués & $0.53 \mathrm{aA}$ & $0.37 \mathrm{bB}$ & $0.67 \mathrm{aA}$ \\
\hline C.V. $(\%)$ & 13.43 & & \\
\hline \multirow{2}{*}{ Cultivars } & \multicolumn{2}{|c|}{$\mathrm{RL}(\mathrm{cm})$} & \multirow{2}{*}{ Control } \\
\hline & Bacillus sp. & Burkholderia ambifaria & \\
\hline BRS-Amazonas & $29.62 \mathrm{aA}$ & $35.88 \mathrm{aA}$ & $33.30 \mathrm{aA}$ \\
\hline BRS-Maués & $26.39 \mathrm{aA}$ & $21.48 \mathrm{bA}$ & $21.69 \mathrm{bA}$ \\
\hline C.V. $(\%)$ & 15.11 & & \\
\hline
\end{tabular}

Note. Means followed by the same letters in the column do not differ among themselves to $5 \%$ of probability by the test of Tukey.

However, for the cultivar BRS-Amazonas, the control did not differ significantly from the treatment with the rhizobacteria Burkholderia ambifaria and for the cultivar BRS-Maués. The control treatment, without inoculation of rhizobacteria, presented better results for root dry matter in the two guarana cultivars. There was no difference in relation to Bacillus sp. (Table 3).

Among the bacteria, Bacillus sp. increased the dry matter weight of the BRS-Maués root when compared to Burkholderia ambifaria. When comparing the cultivars, BRS-Amazonas showed higher weight of root dry matter with the inoculation of Burkholderia ambifaria, in relation to BRS-Maués (Table 3).

For the root length, there was a significant difference between the two guarana cultivars in relation to the Burkholderia ambifaria bacteria.

\subsection{Total Soluble Sugar Content}

The inoculation of the bacteria increased the total soluble sugar content of the BRS-Amazonas cultivar when compared to the control treatment, but did not present any difference between them. However, for BRS Maués, bacteria did not influence the sugar content (Figure 1).

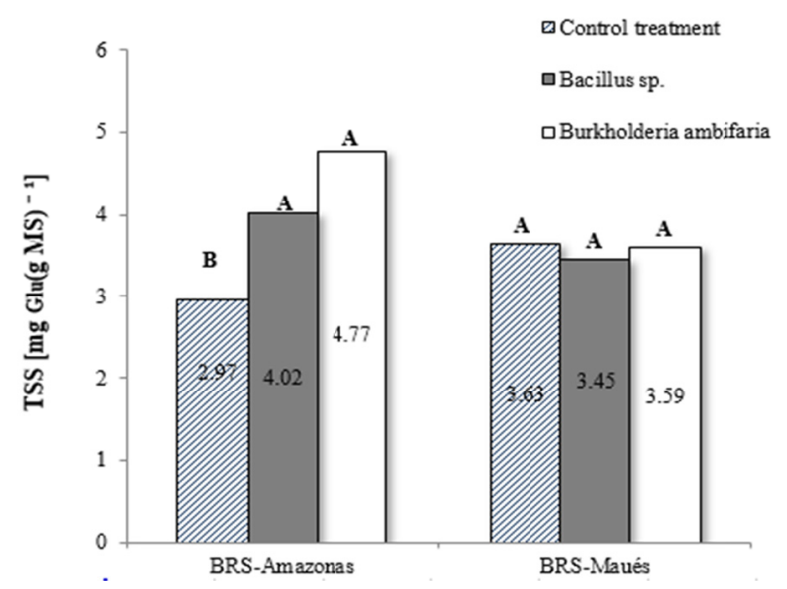

Figure 1. Total soluble sugar content (TSS) of aerial part of two guarana cultivars inoculated or not with rhizobacteria Bacillus sp. and Burkholderia ambifaria. Different upper case letters indicate significant differences between total soluble sugars concentrations within the inoculation treatment by the Scott-Knott test $(\mathrm{p}<0.05)$

In relation to starch, Burkholderia ambifaria also stood out as the best treatment for BRS-Amazonas. For BRS-Maués, no difference was found between treatments (Figure 2). 


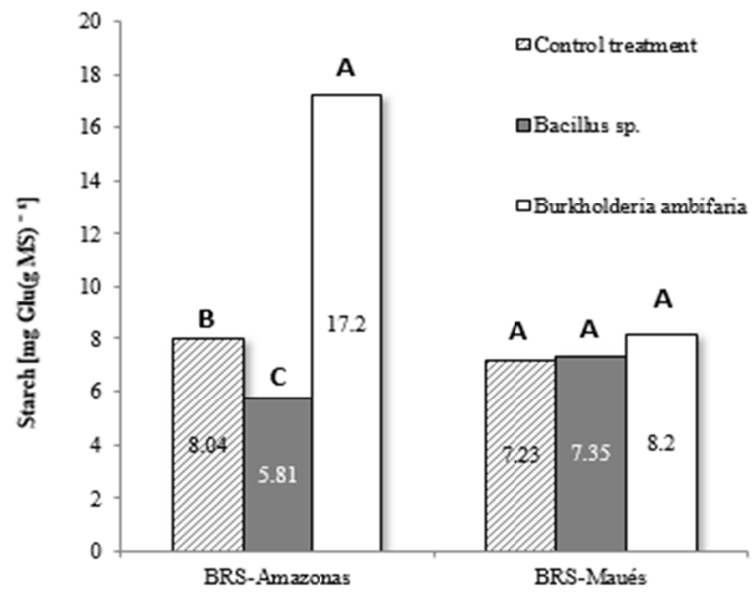

Figure 2. Starch contents (Starch) of aerial part of two guarana cultivars inoculated or not with rhizobacteria Bacillus sp. and Burkholderia ambifaria. Different upper case letters indicate significant differences between total soluble sugars concentrations within the inoculation treatment by the Scott-Knott test $(p<0.05)$

\section{Discussion}

The rhizobacteria can be classified according to their effects on plant growth, beneficial, harmful or neutral, and thus, implement the extent or quality of growth directly or indirectly plant (F. Ahmad, I. Ahmad, \& Khan, 2008). In the literature different results have been found regarding the interaction between plants and these microorganisms.

Strains of Burkholderia fungorum and Burkholderia ambifaria promoted the growth of soil-grown maize by the solubilization of insoluble calcium phosphate, highlighting Burkholderia ambifaria as having greater potential for growth promotion (Oliveira, 2011). However, in soybean, inoculation of the seed with Bacillus sp. and Methylobacterium sp. resulted in a decrease in dry matter of the root and dry matter of the plant compared to the control (Assumpção, Lacava, Armando, Azevedo, \& Menten, 2009), these results agree with those found in this research for guarana.

Even though Batista (2013) has demonstrated the release of auxin by the rhizobacteria Bacillus sp. and Burkholderia ambifaria, other substances with inhibitory or deleterious capabilities may have been synthesized by these rhizobacteria, causing a delay in the development of guarana seedlings in this research.

According to Pedrinho, Galdiano Júnior, Campanharo, Alves, and Lemos (2010), the rhizobacteria can interfere in some stage of development of the plant, being the interaction genotype of the plant and the bacterium, adaptation to environmental conditions, soil type, $\mathrm{pH}$, among others.

These variables demonstrate what can be called the deleterious effect of the bacterium in contact with the plant, with reductions in the leaf area and consequently the rates of photoassimilates, which may have provoked the said responses in the guarana seedlings.

For the proline variable (Table 1), the values found correspond to a good adaptation of the seedlings inoculated with the rhizobacteria, to the biotic and abiotic stresses. This suggests that the plants of the treatments in which the bacteria were inoculated, manage to remain stable.

Proline accumulation is linked to responses to plant stress conditions (Verbruggen \& Hermans, 2008). All of these events are related to factors that affect root growth and shoot growth. This accumulation provides an important parameter for the selection of resistant plants (Verbruggen \& Hermans, 2008).

The accumulation of proline was different in relation to the cultivars. If the accumulation of proline is low in a cultivar, this can be considered a factor of better adaptability of this cultivar.

There are specific characteristics for each guarana cultivar, in relation to medium adaptation, resistance to diseases, growth, development and productivity, that allow the selection of superior individuals, with more desirable characteristics for direct use by the producers or in programs of genetical enhancement. Therefore, adaptation to stress levels are also points to be considered in choosing a cultivar, proving that they adapt in a varied way to changes in the environment. 
In the interaction between the cultivars of rhizobacteria and guarana, the differences found between the cultivars of Burkholderia ambifaria and in the control treatment are probably related to the genetic variability of guarana. The same may have occurred in the dry matter of the root.

This indicates that some rhizobacteria may promote growth in one species of plant and be ineffective in others, as demonstrated in a study of inoculation with rhizobacteria in Eucalyptus leaflets (Teixeira et al., 2007). Such results can be explained by the fact that growth-promoting substances produced by bacteria can be highly specific to certain plant species or even cultivars, as well as to different environments where they are inserted, or, in turn, due to the stress they causes. The community may be suffering due to environmental and anthropogenic changes (Jha et al., 2009, Oliveira, 2009, Prakamhang, Minamisawa, Teamtaisong, Boonkerd, \& Teaumroong, 2009).

The fact that the treatments did not have, in the majority, promoted the growth of the guarana plants can be attributed to several factors: stress suffered by the seeds during the threshing, elimination of epiphytic micro-organisms or even small variations in the balance of the endophytic bacterial population which may have caused an imbalance in the beneficial and deleterious substances produced by the bacteria.

The results obtained in this work reinforce the idea that the promotion of plant growth is a complex phenomenon that is achieved by the simultaneous activity of several microorganisms and factors. Not always the rhizobacteria can promote the growth of plants, and there are several reports of inconsistency in the results, in which a rhizobacterium is sometimes beneficial, but has no effect on plant growth.

The low growth rates observed in the guarana seedlings in the presence of the microorganisms may have also been influenced by the amount and composition of the exudates released by the plant, interfering in the rhizospheric competence of these bacteria. Such compounds available in varied quantity and quality can select specific functional groups (Moreira \& Siqueira, 2006).

The availability of AIA exerted by the bacteria may have slowed down the growth and development of the plant, causing the decrease of its growth and consequently its deleterious effects on the plant. Concentrations of growth promoting substances, such as auxin, promoted by the presence of bacteria in the plant, stimulate their growth as long as it is in low concentrations. At high concentrations this effect changes from beneficial to deleterious or toxic, suggesting that inoculation with a large number of viable bacterial cells may cause a negative effect rather than stimulating root growth.

The levels of AIA produced by bacteria depend on bacterial growth, metabolic activity and the expression of genes that encode enzymes for their biosynthesis, which would explain part of the variations observed between the analyzed parameters of the plant (growth in height, number of leaves and dry weight of shoot and root) (Spaepen, Vanderleyden, \& Remans, 2007).

Batista (2013), analyzing the auxin concentration of the rhizobacteria Burkholderia ambifaria and Bacillus sp., inoculated on maize seeds, presented the mean production of AIA $\left(\mu \mathrm{g} \mathrm{mL}^{-1}\right)$ in 49,871 and 16,102 , respectively. This fact corroborates with the authors mentioning the deleterious action of rhizobacteria when they excreted high concentrations of auxin.

The adjustment of the bacterial suspension to $10^{4} \mathrm{cfu} \mathrm{mL}^{-1}$, may be another factor to be considered in the results of this research, since no preliminary studies were done on the optimum concentration of rhizobacteria for the inoculation stage in seeds and in the transplantation to plastic bags.

Most of the works with RPCPs mainly discuss the beneficial effect of these bacteria, however, the occurrence of negative effects is reported by some authors cited here and that may also be correlated with the tested microorganism species and its host.

In sugarcane genotypes inoculated with the bacterium Glucanoacetobacter, there was also an increase in total soluble sugars when compared to the genotypes inoculated with the Herbaspirillum bacterium (Marcos, 2012).

Soluble sugars, besides being sources of carbon for maintenance and recovery of growth, are also considered as osmotically active molecules, as well as proline. The increase in the concentration of these molecules is a protection strategy, since these solutes contribute to osmotic adjustment, stabilization of membranes of structures of enzymes and proteins (Farooq, Wahid, Kobayashi, Fujita, \& Basra, 2009).

In relation to the starch, Burkholderia ambifaria was highlighted as a better treatment for raising carbohydrate contents by more than $100 \%$ in the leaves of BRS-Amazonas (Figure 2).

Barka, Nowak, and Clément (2006) showed that plants treated with a strain of Burkholderia phytofimans had an increase in the levels of proline, starch and phenolic compounds. 
Photosynthetically active tissues, such as mature leaves considered as source, produce more carbohydrates than they need to maintain their metabolism and growth, exporting surplus photoassimilates in the form of sucrose or starch. However, source-drain relationships are not static (Leite, Crusciol, Lima, \& Silva, 2009).

However, even with higher availability of starch in the leaves, especially in the cultivar BRS-Amazonas inoculated with the bacterium Burkholderia ambifaria, there seems to have been a low translocation of these photoassimilates to the roots and with that, a low increase in the length and dry matter of the same.

A hypothesis to be considered as a response to these data may be related to the relationship between auxin and cytokinin, since chemical messengers, such as hormones and nutrients, are factors that also control the source/drain relationship of assimilates (Taiz \& Zeiger, 2009).

When a high concentration of cytokinin occurs in some organs of the plant, such as leaves, it causes translocation of assimilates to the treated area, indicating that this phytohormone increases the strength of the drain. The assimilates in the source leaf are directed to the nearest strong drains, which means that the leaves of the upper third direct the assimilates to the apices and new leaves in development (Marenco \& Lopes, 2009).

Plant regulators can promote, inhibit or modify the physiological growth processes of a plant, they are products that act in low concentrations, so any kind of change can influence the expected results.

Works using Bacillus sp. and Burkholderia ambifaria in promoting growth of guarana plants are non-existent. Thus, these results are pioneers with the use of microorganisms in the promotion of growth of guarana plants, constituting the first studies with these bacteria in an endophytic form.

\section{Conclusions}

The inoculation of the rhizobacteria did not promote an increase in the growth of guarana seedlings.

Inoculation of rhizobacteria increased carbohydrate contents and reduced proline content in guarana seedlings.

\section{References}

Ahmad, F., Ahmad, I., \& Khan, M. S. (2008). Screening of free-living rhizospheric bacteria for their multiple plant growth promoting activities. Microbiological Research, 163(2), 173-181. https://doi.org/10.1016/ j.micres.2006.04.001

Assumpção, L. C., Lacava, P. T. D., Armando, C. F., Azevedo, J. L., \& Menten, J. O. M. (2009). Diversity and biotechnological potential of endophytic bacterial community of soybean seeds. Pesquisa Agropecuária Brasileira, 44(5), 503-510. https://doi.org/10.1590/S0100-204X2009000500010

Avis, T. J., Gravel, V., Antoun, H., \& Tweddell, R. J. (2008). Multifaceted beneficial effects of rhizosphere microorganisms on plant health and productivity. Soil Biology and Biochemistry, 40(7), 1733-1740. https://doi.org/10.1016/j.soilbio.2008.02.013

Barka, E. A., Nowak, J., \& Clément, C. (2006). Enhancement of chilling resistance of inoculated grapevine plantlets with a plant growth-promoting rhizobacterium, Burkholderia phytofirmans strain PsJN. Applied and Environmental Microbiology, 72(11), 7246-7252. https://doi.org/10.1128/AEM.01047-06

Batista, B. D. (2013). Growth promotion in maize (Zea mays L.) by rhizobacteria associated with guarana crop (Paullinia cupana var. sorbilis) (Doctoral dissertation, São Paulo University, São Paulo, Brazil).

Baldani, V. (2007). Protocol for the analysis of the quality and agronomic efficiency of inoculants, strains and other elites related to the process of biological nitrogen production in non-leguminous plants. Annals (Documents 290, pp. 124-142). Londrina: Embrapa Soja.

Farooq, M., Wahid, A., Kobayashi, N., Fujita, D., \& Basra, S. M. A. (2009). Plant drought stress: Effects, mechanisms and management. Sustainable agriculture (pp. 153-188). Springer, Dordrecht. https://doi.org/ 10.1007/978-90-481-2666-8_12

Galdiano, J. R. F. (2009). Identification and inoculation of auxin-producing bacteria associated with orchid roots (Doctoral dissertation, Paulista State University, Jaboticabal, São Paulo, Brazil). Retrieved from http://hdl.handle.net/11449/92702

Grobelak, A., Napora, A., \& Kacprzak, M. (2015). Using plant growth-promoting rhizobacteria (PGPR) to improve plant growth. Ecological Engineering, 84, 22-28. https://doi.org/10.1016/j.ecoleng.2015.07.019

Jha, B., Thakur, M. C., Gontia, I., Albrecht, V., Stoffels, M., Schmid, M., \& Hartmann, A. (2009). Isolation, partial identification and application of diazotrophic rhizobacteria from traditional Indian rice cultivars. European Journal of Soil Biology, 45(1), 62-72. https://doi.org/10.1016/j.ejsobi.2008.06.007 
Leite, G. H. P., Crusciol, C. A. C., Lima, G. P. P., \& Silva, M. D. A. (2009). Growth regulators and activity invertases in the middle of the cropping season. Ciência Rural, 718-725. https://doi.org/10.1590/S010384782009000300014

Marcos, F. C. C. (2012). Influence of endophytic bacteria on the physiology of sugarcane plants under water restriction (Doctoral dissertation, Agronomic Institute of Campinas, Campinas). Retrieved from http://www.iac.sp.gov.br/areadoinstituto/posgraduacao/dissertacoes/pb1211410\%20Fernanda\%20Castro\%2 0Correia\%20Marcos.pdf

Marenco Mendoza, R., \& Lopes, N. F. (2005). Fisiologia vegetal: Fotossíntese, respiração, relações hídricas, nutrição mineral. Minas Gerais, UFV.

MCcready, R. G., \& Guggolz, J. J., Silviera, V., \& Owens, H. S. (1950). Determination of starch and amylase in vegetables. Anal. Chem., 22, 1156. https://doi.org/10.1021/ac60045a016

Moreira, F. M. S., \& Siqueira, J. O. (2002). Microbiologia e bioquímica do solo Lavras. Editora UFLA.

Oliveira, S. M. (2011). Rhizobacteria promote the growth of common bean and corn by different processes (Unpublished Doctoral dissertation, Federal University of Lavras, Lavras, Minas Gerais).

Oliveira, Z. M. (2009). Rhizobacteria that promote plant growth isolated from sugarcane under organic and/or conventional biofertilization (Doctoral dissertation, Institute of Biomedical Sciences, USP, São Paulo).

Pedrinho, E. A. N., Galdiano Júnior, R. F., Campanharo, J. C., Alves, L. M. C., \& Lemos, E. G. D. M. (2010). Identification and evaluation of bacteria isolated from roots of maize. Bragantia, 905-911. https://doi.org/10.1590/S0006-87052010000400017

Prakamhang, J., Minamisawa, K., Teamtaisong, K., Boonkerd, N., \& Teaumroong, N. (2009). The communities of endophytic diazotrophic bacteria in cultivated rice (Oryza sativa L.). Applied Soil Ecology, 42(2), 141-149. https://doi.org/10.1016/j.apsoil.2009.02.008

Rena, A. B., \& Masciotti, G. Z. (1976). The effect of dehydration on nitrogen metabolism and growth of 4 bean cultivars (Phaseolus vulgaris L.). Revista Ceres, Viçosa, 23(128), 288-301.

Schimpl, F. C., da Silva, J. F., de Carvalho Gonçalves, J. F., \& Mazzafera, P. (2013). Guarana: Revisiting a highly caffeinated plant from the Amazon. Journal of Ethnopharmacology, 150(1), 14-31. https://doi.org/ 10.1016/j.jep.2013.08.023

Solano, B. R., Maicas, J. B., \& Mañero, F. G. (2008). Physiological and molecular mechanisms of plant growth promoting rhizobacteria (PGPR). Plant-bacteria interactions: Strategies and techniques to promote plant growth (pp. 41-52). Wiley, Weinheim, Germany. https://doi.org/10.1002/9783527621989.ch3

Spaepen, S., Vanderleyden, J., \& Remans, R. (2007). Indole-3-acetic acid in microbial and microorganism-plant signaling. FEMS Microbiology Reviews, 31(4), 425-448. https://doi.org/10.1111/j.1574-6976.2007.00072.x

Taiz, L., Zeiger, E., Møller, I. M., \& Murphy, A. (2009). Fisiologia e desenvolvimento vegetal. Artmed Editora.

Teixeira, D. A., Alfenas, A. C., Mafia, R. G., Ferreira, E. M., Siqueira, L. D., Maffia, L. A., \& Mounteer, A. H. (2007). Rhizobacterial promotion of eucalypt rooting and growth. Brazilian Journal of Microbiology, 38(1), 118-123. https://doi.org/10.1590/S1517-83822007000100025

Verbruggen, N., \& Hermans, C. (2008). Proline accumulation in plants: A review. Amino Acids, 35(4), 753-759. https://doi.org/10.1007/s00726-008-0061-6

\section{Copyrights}

Copyright for this article is retained by the author(s), with first publication rights granted to the journal.

This is an open-access article distributed under the terms and conditions of the Creative Commons Attribution license (http://creativecommons.org/licenses/by/4.0/). 